\title{
Effects of the Credit Boom on the Soundness of Vietnamese Commercial Banks
}

\author{
Hao Thi Kim Do ${ }^{1}$, Nguyet Thi Minh Nguyen ${ }^{1} \&$ Trung Hai Le ${ }^{1}$ \\ ${ }^{1}$ Banking Academy of Vietnam, Vietnam \\ Correspondence: Hao Thi Kim DO, Banking Academy of Vietnam, Vietnam.
}

Received: May 10, 2017

Accepted: June 8, 2017

Online Published: June 20, 2017

doi:10.5430/ijfr.v8n3p57

URL: https://doi.org/10.5430/ijfr.v8n3p57

\begin{abstract}
This paper concentrates on examining the impact of the credit boom (2007-2010) on the soundness of the commercial banking system in Vietnam by using qualitative and quantitative methods. The results show that the credit boom in the period 2007-2010 had made Vietnam's banking system face many uncertainties such as difficulties in liquidity, increased non-performing loans... The influence of the credit boom on Vietnam's banking system is assessed on basic aspects such as asset quality, profitability, liquidity, capital adequacy... The quantitative analysis of the impact is made through the regression model using variables that show the characteristic of individual commercial bank and the volatility of the economy. The data is collected from 18 commercial banks in Vietnam in the period from 2005 to 2013, taken from the database BankScope and supplemented by information from the annual financial reports of the banks. Finally, in order to avoid the possibility of credit booms in the future and their effects on bank soundness in Vietnam, some recommendations related to credit growth are proposed for the authorities and the commercial banks.
\end{abstract}

Keywords: credit boom, credit growth, bank soundness, commercial banks

\section{Introduction}

In countries with underdeveloped financial markets like Vietnam, bank lending is considered as one of the important sources of capital for investment and development. In the past few years, the fact that bank credit has continued to grow has contributed significantly to the total investment of the whole economy, promoting economic growth. However, this does not mean that the higher the credit growth has been, the more the economy has grown. Clearly, in many countries, excessive credit growth can negatively affect the soundness of the banking system, then cause economic instability (Kindleberger, 1977; Sirtaine and Skamnelos, 2007).

In recent years, the world has witnessed turmoil in the banking system stemming from the credit booms such as the banking crisis in Japan in the 1990s, the subprime crisis in the US in 2008. Studies have shown that credit growth and the soundness of the banking system are interrelated (Gourinchas, 2001). Sound banks will be more likely to expand their lending activities thanks to their strong financial and human resources. However, when credit growth is too high, it will be possible to weaken the banks, which could lead to the banking system's crisis in the worst case. This happens not only in sound banks but also in weak ones who are very risk takers for credit extension.

In Vietnam, banking credit was considered to be credit boom in some time, especially in the period 2007-2010 when the total credit to GDP ratio was above 10\%, up to $28 \%$ in 2007 and 30\% in 2009. 


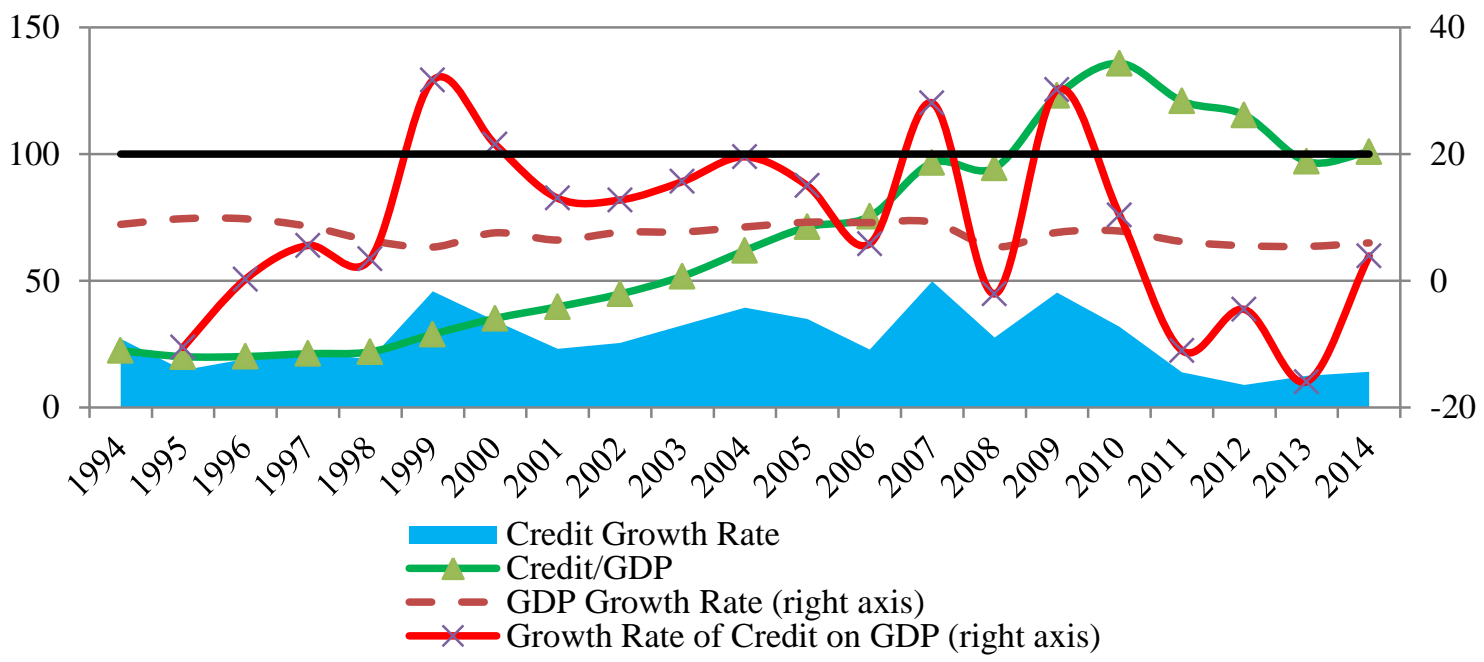

Figure 1. Credit of the commercial banking system in Vietnam during 1994-2014 (\%)

Source: Authors' compilation.

The paper aims to assess the effects of the credit boom from 2007 to 2010 on the soundness of Vietnamese commercial banks on some key aspects such as profitability, capital adequacy, asset quality. On that basis, recommendations in terms of credit growth that are for regulatory authorities and commercial banks are proposed in order to limit the likelihood of credit booms and their effects on bank soundness in Vietnam.

\section{Overview of the Impact of the Credit Boom between 2007 to 2010 on the Soundness of Vietnamese Commercial Banks}

Since 2008, as in many countries in the world, Vietnam has suffered from the severe effects of the global financial crisis in 2008 and the public debt crisis in Europe started in 2010. Furthermore, the internal turmoil of the economy has emerged such as increased trade deficit, budget deficit, rising public debt, high inflation and slow economic growth. This has partly caused the banking system of Vietnam to face many uncertainties, including liquidity problems and non-performing loans (Quach Manh Hao, 2012; KPMG, 2013). There is widespread agreement that the excessive credit expansion in the period 2007-2010 along with the expansion in terms of the number and size of the banking system was considered to be the underlying cause of the deterioration of the soundness of Vietnam's banking system at a later stage because the credit boom has reduced the marginal benefit of credit to the Vietnamese economy. The impact of the credit boom between 2007 to 2010 on the soundness and safety of the banking system in Vietnam has been reflected in the following aspects.

\section{The quality of bank assets}

The credit boom has contributed to the deterioration of credit quality through the NPL ratio of Vietnam's banking system which has grown rapidly from 2011, though the credit growth rate has started to decline in 2012 (Banking Academy, 2013). This has reflected the new bad debt has arisen mainly from the credits granted previously, especially during the excessive credit growth period 2007-2010. 


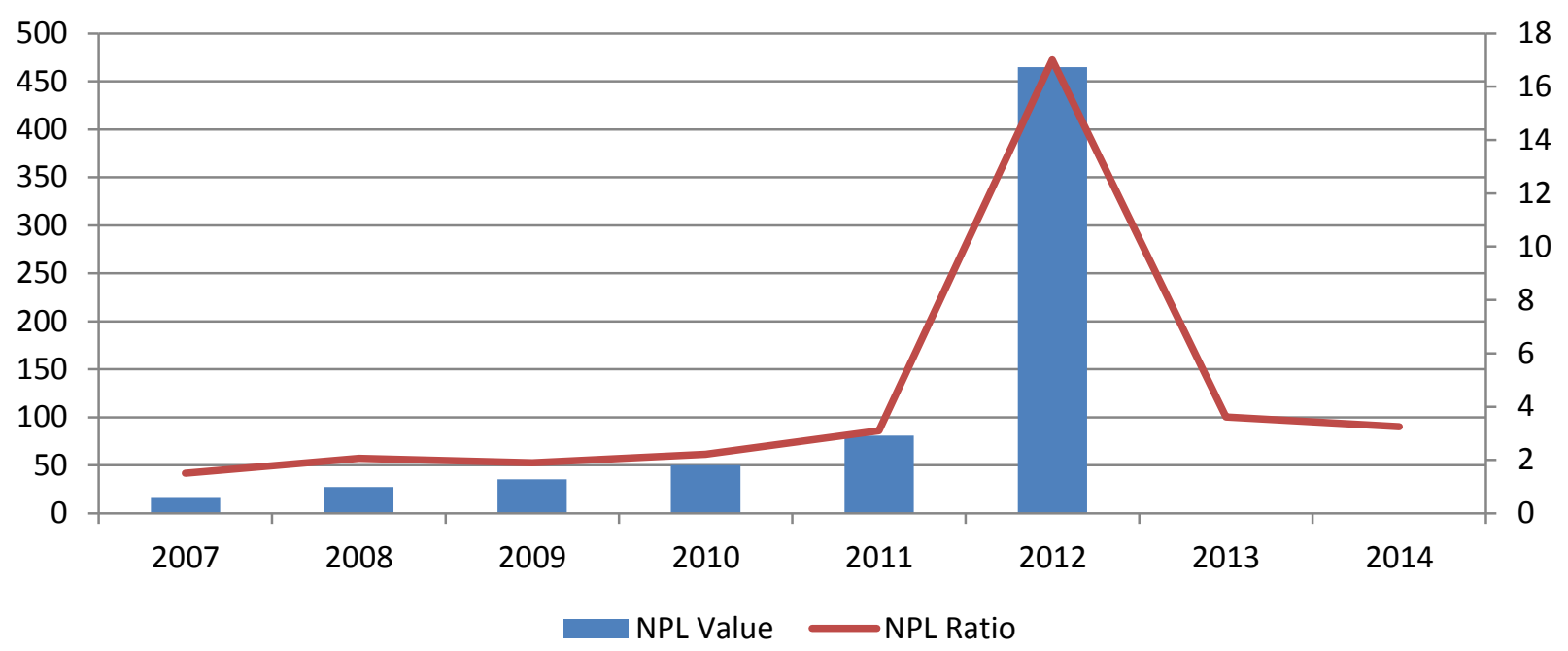

Figure 2. NPL value (trillion dong) and NPL ratio (\%)

Source: Authors' compilation

Non-performing loans in Vietnamese banks has increased sharply due to a variety of causes, such as unfavorable economic environment, poor corporate governance, falling investment efficiency, and inadequacies in credit risk management (To Ngoc Hung, 2013). The shortcomings in credit risk management have been reflected in the prolonged unreasonableness of the credit structure of the banking system in Vietnam. Along with the credit boom from 2007 to 2010, this not only has led to an unsustainable economic growth but also to the banking system facing credit risk, in turn resulting in consequent bad debt.

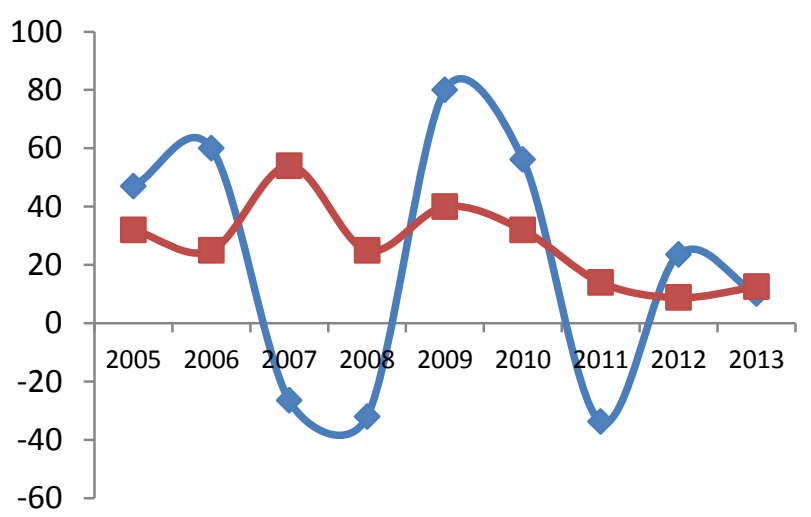

The growth of security trading credit

- Credit growth of the banking system

Figure 3. The proportion of security trading credit (\%)

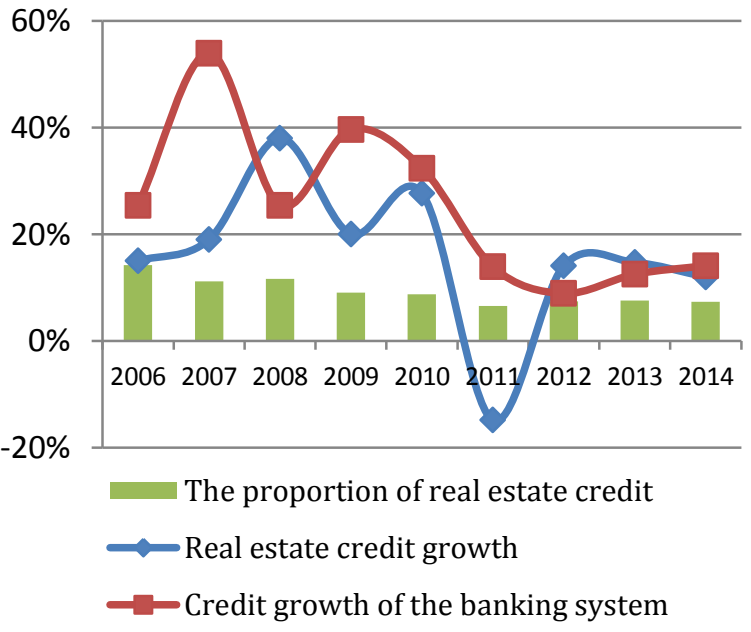

Figure 4. The proportion of real estate credit

Source: Authors' compilation

The restrictions of the credit structure have been expressed primarily in two respects. Firstly, credit inflows into risky sectors such as real estate and stock trading have made the banking system unstable. A large amount of credit flowing into stock and real estate trading has created bubbles in the real estate and stock markets. This is the reason why bad debt has been accumulated in a long time and the banking system has faced risks when these markets have gradually 
adjusted to real value after the period of excessive credit growth. Secondly, around $20 \%$ of bank lending has been allocated to state-owned enterprises (SOEs) which have been with poor capital efficiency (high ICORs). In addition, SOEs' debt has mainly been without collateral (KPMG, 2013). Therefore, the commercial banks have incurred increased bad debt.

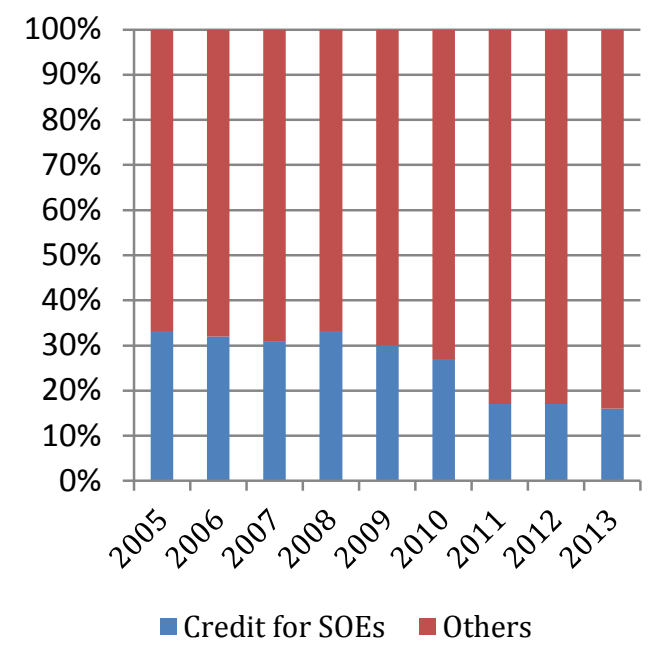

Figure 5. Credit for SOEs

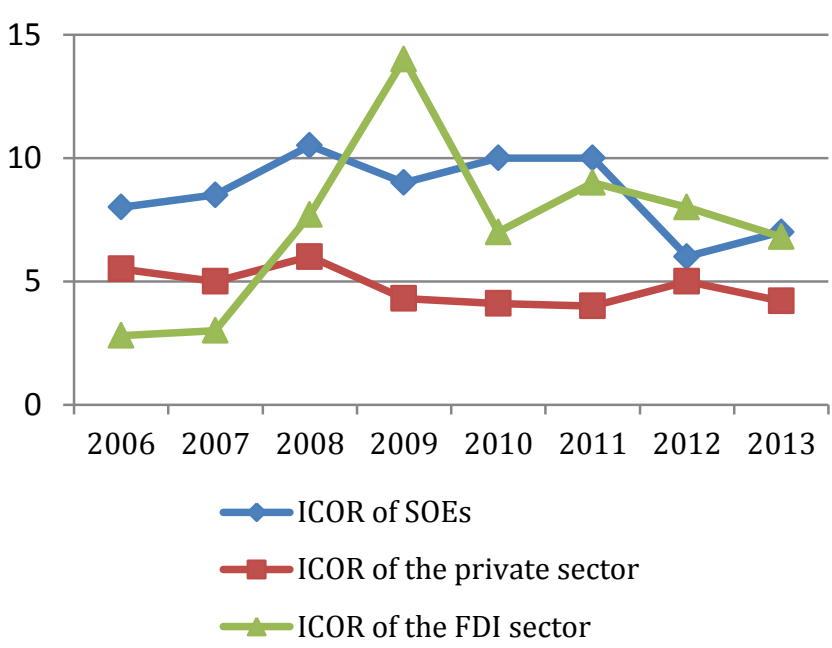

Figure 6. The incremental capital output ratios (ICOR)

in Vietnam during 2006 - 2013

Source: Authors' compilation

\section{Liquidity risk}

In the period 2008-2011, liquidity stress had been occurring frequently in the banking system in Vietnam. The main cause was that the credit growth had usually been higher than the deposit one for a long time from even before, leading to a serious imbalance between assets and liabilities. During the period 2005-2010, the average credit growth reached $30 \%$ per annum while the deposit growth averaged $21.17 \%$ per year according to the State Bank of Vietnam. This difference made loan-to-deposit ratios very high (80-90\%). Although the banking system's liquidity improved in the 2012-2013 period, the loan-to-deposit ratios remained relatively high over $80 \%$, compared to under $80 \%$ in Asian countries or $30-40 \%$ in developed ones. 


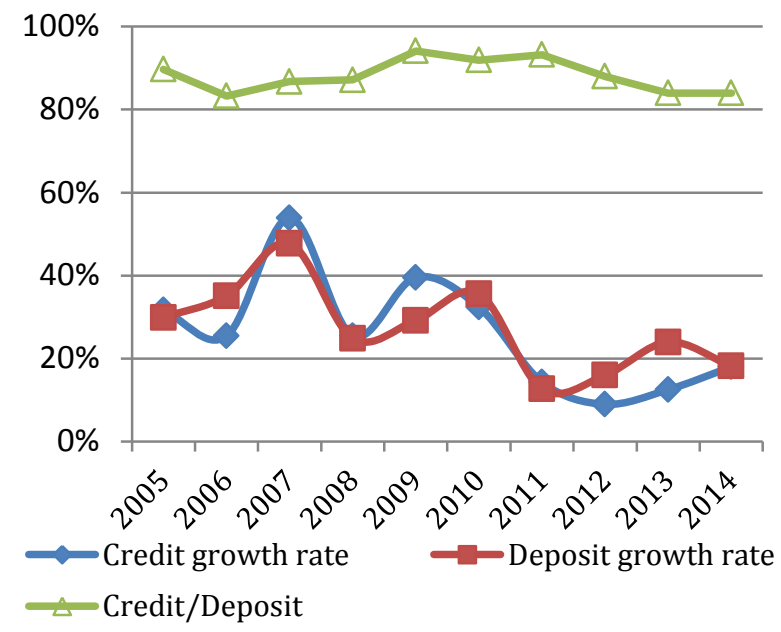

Figure 7. Credit and deposit growth,

credit to deposit ratio of the banking system in Vietnam

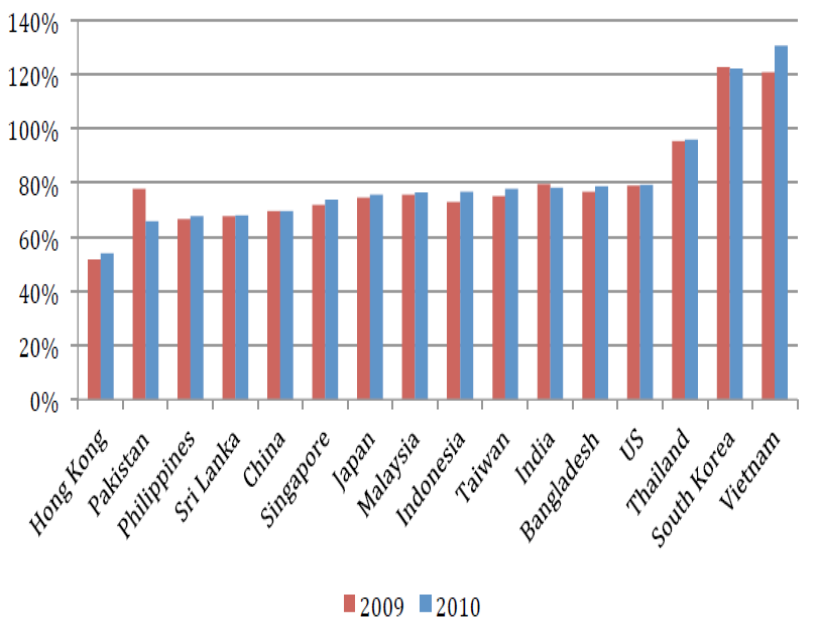

Figure 8. Credit to deposit ratios of the banking system in some countries

Another reason for the high liquidity risk was the maturity imbalance between deposits and lending of the banking system because the increased credit during 2007 and 2010 was allocated for medium-term and long-term loans of up to $40 \%$ while short-term deposits were roughly $80 \%$ (Quach Manh Hao, 2012).

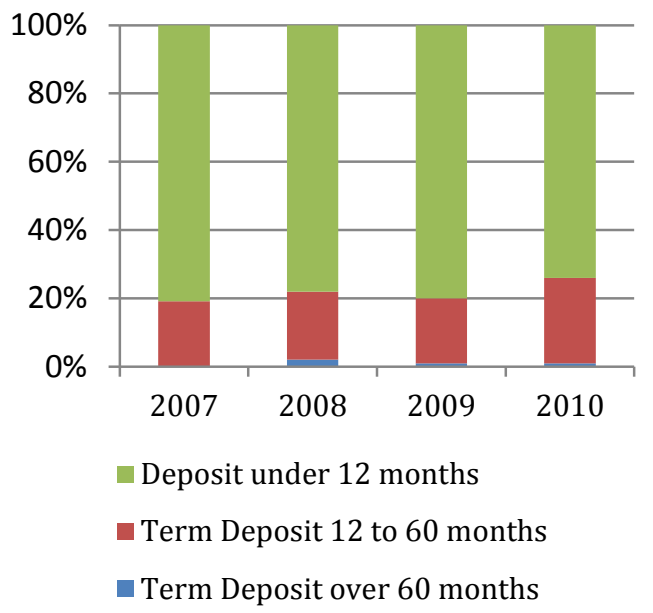

Figure 9. Deposit structure by the term of the banking system Vietnam

Source: Authors' compilation

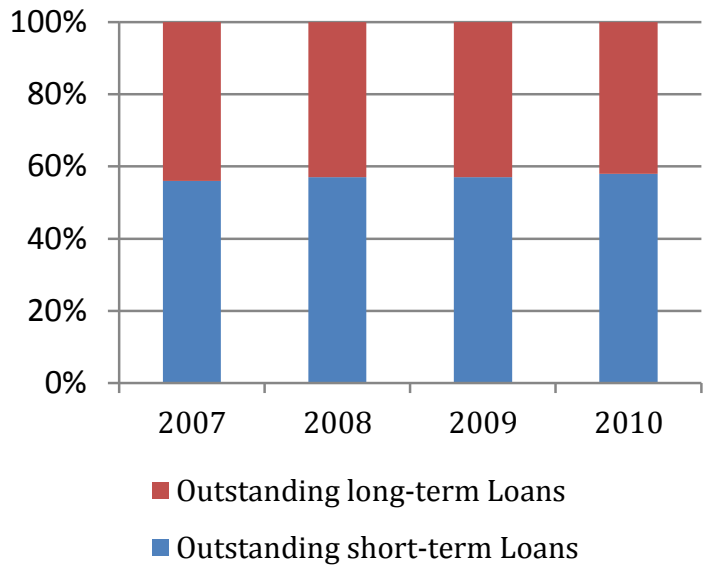

Figure 10. Credit structure by the term of the banking system Vietnam

\section{Profitability of the banking system}

The low credit growth following the credit boom period along with the fact that the whole banking system has been paying attention to the handling of non-performing loans has resulted in a sharp decline in profitability of the banks in terms of ROA and ROE. Clearly, bank income is largely dependent on lending which is the main activity of commercial banks. The ratio of credit to total asset and that of interest income to total income are usually high in Vietnam (Banking Academy, 2013). In addition, the decrease in income from lending activities together with the increase in risk provisions due to increased NPLs have contributed to the reduction of commercial banks' profits. 
This is because according to the regulations of the State Bank of Vietnam, in order to deal with their NPLs, commercial banks must deduct their profits for loan loss provisions.

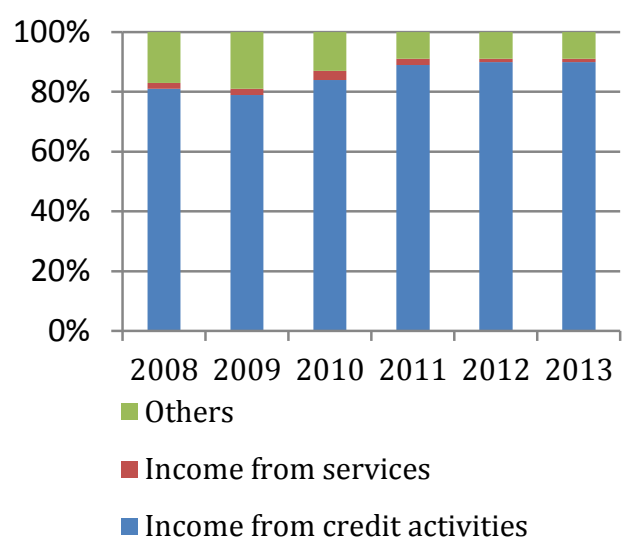

Figure 11. Income structure

of the banking system in Vietnam

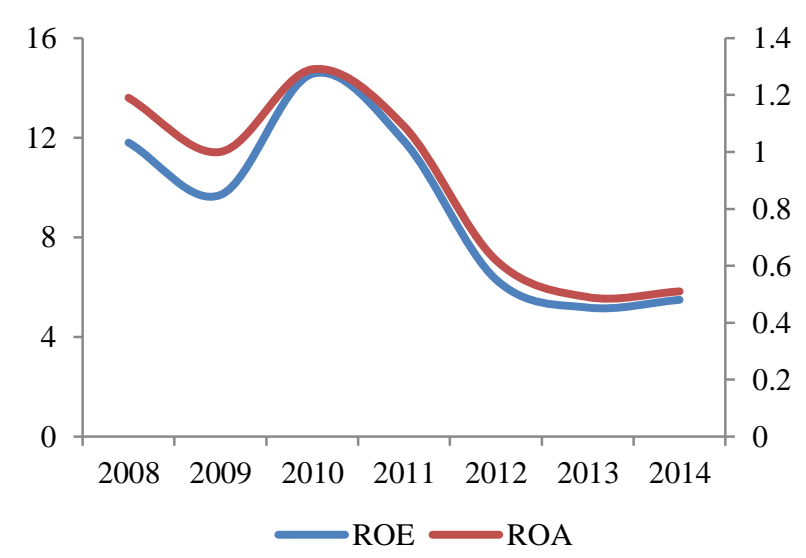

Figure 12. ROA, ROE of the banking system in Vietnam

Source: The SBV's website

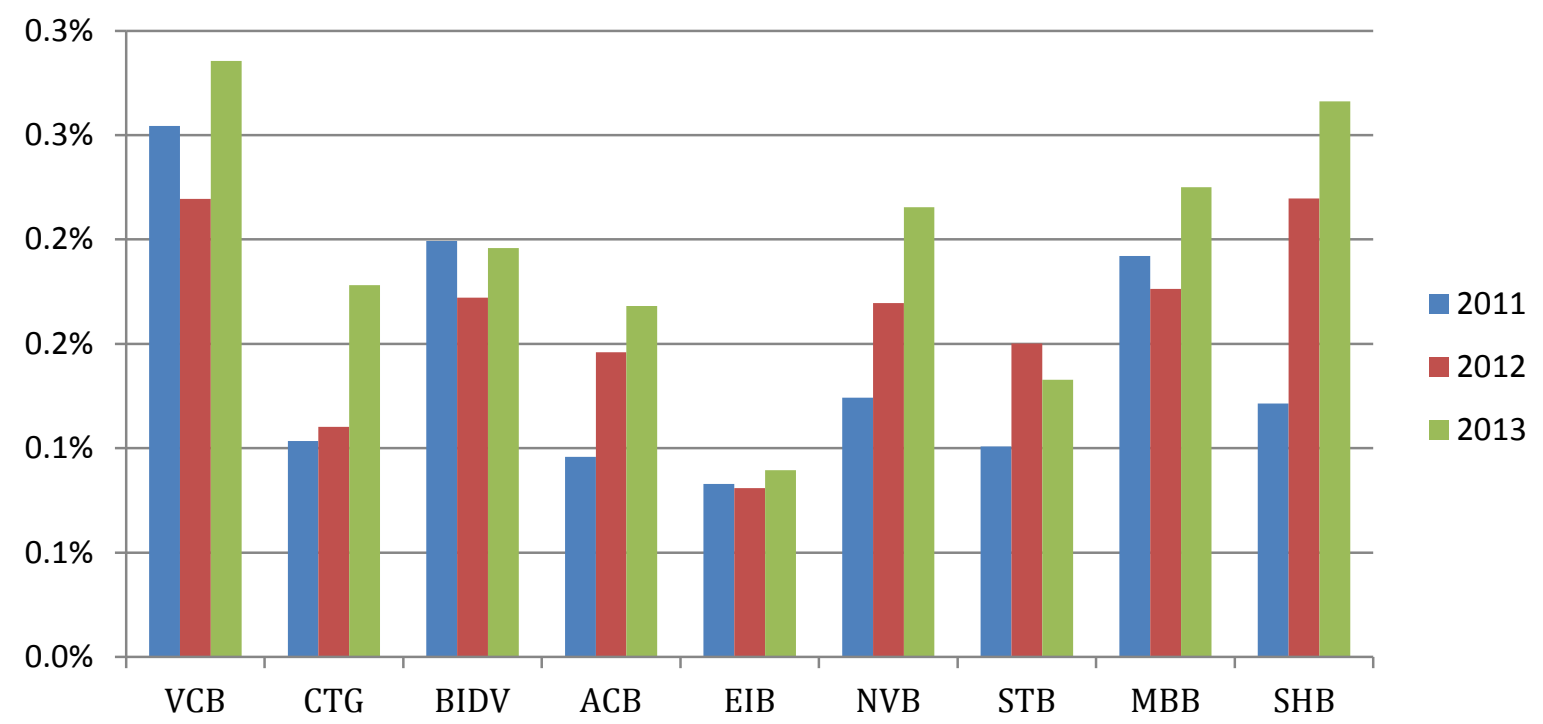

Figure 13. Credit loss provision ratios of some listed banks

Source: Financial statements of the commercial banks

\section{Capital adequacy}

The consequence of NPLs, especially from 2011, not only has put pressure on risk provisions but also has threatened to the safety of the banking system in terms of the risk of decreasing capital adequacy ratio (CAR). In addition, because the banking sector's performance has been weakened by the low credit growth after the credit boom phase, capital growth has been low in the latter period, lowering the capital adequacy ratio. It can be clearly seen from the below chart after the excessive credit growth period the CAR and leverage ratio of the whole banking system increased until 2011 and thereafter decreased from 2012. 


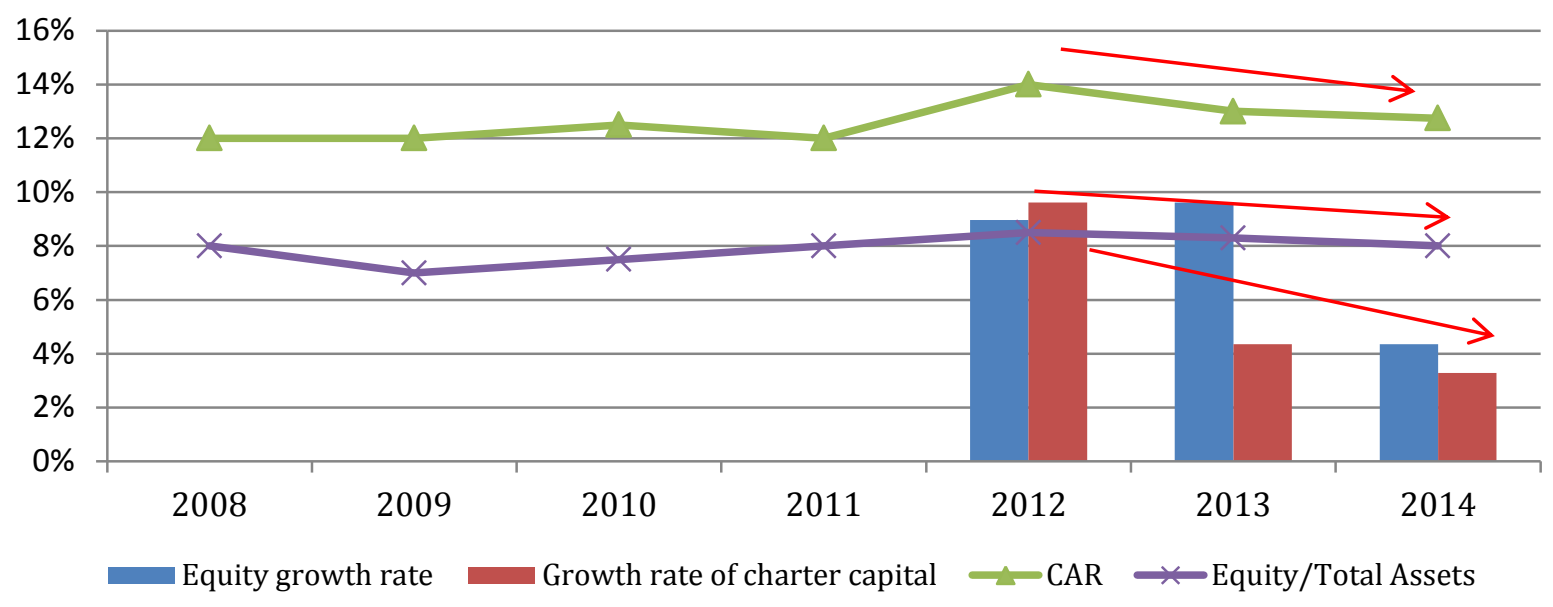

Figure 14. The ratio of equity to total assets, CAR of the banking system in Vietnam

Source: The SBV's website

In summary, the credit boom from 2007 to 2010 has had considerable effects on the macroeconomic stability in general and the soundness of the banking system in particular. This has been a consequence of the broad-based growth model of the banking system in Vietnam. In other words, the system has focused too much on the expansion of total assets through credit growth without regard to the quality of bank lending and bank governance.

\section{Methodology}

The assessment of the impact of the credit boom between 2007 and 2010 on the soundness of Vietnamese commercial banks is reflected in the some aspects such as asset quality, profitability, capital adequacy, and "distance to default" (z-score), as well as other variables that depend on the characteristics of individual commercial bank and the economy.

\subsection{Data Description}

The data is collected from 18 Vietnamese commercial banks in the BankScope database, ranging from 2005 to 2013 in annual frequency, and supplemented with information from their annual financial reports. The banks selected for the sample should remain active until the end of 2013 with continuous statistics for at least 6 years. At the same time, the banks need to ensure their representation of the Vietnamese banking system which is divided into three main groups: State-owned commercial banks (SOCBs); Joint stock commercial banks and Foreign Commercial banks or Joint ventures. The total assets of the selected banks account for more than $85 \%$ of the total assets of the whole system as of 2013. The macro data used in the study is collected from statistical reports and information disclosure by the General Statistics Office of Vietnam; State Bank of Vietnam, the International Monetary Fund and the Worldbank during the same period.

\subsection{Dependent Variables}

This study first examines the relationship between credit growth and the soundness of commercial banks in Vietnam, followed by an assessment of this impact during the period of the credit boom from 2007 to 2010.

Credit growth (bankCrgr $\left.{ }_{i t}\right)$ is represented by the annual growth rate of lending at the selected commercial banks, of which, lending is determined as the total credit amount that the commercial banks have allocated to the economy. As the data is collected annually, it is collected from the annual financial statements of the banks and is not adjusted for seasonal factors.

Regarding the soundness of the commercial banks, four aspects of their business operations are considered, namely profitability, asset quality, capital adequacy as recommended by the International Monetary Fund and "distance to default" (z-score), which has been chosen by many previous researchers including Black and Scholes (1973), Ghosh (2010), Igan and Pinheiro (2011). 
The return on equity $\left(\mathbf{R O E}_{\mathbf{i t}}\right)$ is used to represent the profitability of 18 commercial banks. It demonstrates their ability to generate profits and added value for their shareholders. The rate of ROE is considered one of the most comprehensive indicators of the commercial banks' profitability, since, after all, the most important objective of a commercial bank is to maximize its net worth as well as added value for its shareholders. The variable of ROE has always been one of the most commonly used variables in most empirical research on commercial profitability, such as Goddard et al. (2004), Hoffmann (2011).

For asset quality, the ratio of provision for credit losses on lending (LLRGL $\mathbf{L}_{\text {it }}$ ) at the commercial banks mentioned is used instead of the NPL ratio. Most empirical studies use a NPL ratio to reflect the quality of the loan portfolio, however, in Vietnam it is not the case due to the lack of regulation related to debt classification. (To Ngoc Hung, 2013)

The equity-to-total capital ratio $\left(\mathbf{C A P}_{\text {it }}\right)$ is chosen to represent the capital adequacy of 18 commercial banks. Commercial banks often use a high degree of financial leverage as financial intermediaries in the economy since the main source of capital is raised from holders who have excess capital. However, if the financial leverage ratio is too high (the $\mathbf{C A P}_{\text {it }}$ is too low), commercial banks will become more vulnerable to adverse changes in the economy. Therefore, a high $\mathbf{C A P}_{\text {it }}$ ratio will demonstrate greater safety in commercial banks' capital, helping commercial banks avoid large losses due to abnormal shocks to the economy.

In addition to the mentioned variables, most empirical studies use "distance to default" (zscore ${ }_{\text {it }}$ ) to represent the soundness of a commercial bank (Igan and Pinheiro, 2011; Ghosh, 2010). The zscore ${ }_{\text {it }}$ used in this study is the simple form proposed by De Nicolo et al. (2005), Black and Scholes (1973) and Merton (1974). The larger the zscore $_{\text {it }}$ is, the safer commercial banks are at their financial leverage and current profitability.

\subsection{Independent Variables}

Independent variables are divided into two groups, which include the group of variables representing the characteristics of individual commercial bank and the group of macro variables showing the impact of macro factors.

\section{- Macro variables}

The selected macro variables show the impact of credit demand on credit growth of single commercial bank as well as their profitability or risk.

The real GDP growth rate ( (realGDP $_{\text {it }}$ ) is a variable representing the demand for credit capital of the economy. When the economy is booming (high GDP growth), there will be more investment opportunities, which causes the demand for bank lending to increase. This is particularly true for Vietnam which has the bank-based financial system.

The real lending interest rate ( $\mathbf{r e a l I}_{\mathrm{it}}$ ) is another variable that also indicates the need for credit capital of the economy. As real interest rate increases, real borrowing costs rises accordingly. For that reason, real interest rate is expected to reverse in line with credit growth of commercial banks.

The change of the real multilateral exchange rate $\left(\mathbf{d e l R e e} \mathbf{R}_{\mathrm{it}}\right.$ ) demonstrates the need for credit in foreign currency loans. At the same time, exchange rate fluctuations also have a certain impact on the safety of commercial banks (Igan and Pinheiro, 2011).

Besides expressing the effect on credit demand, the mentioned macro variables show changes in the economic environment and risks in business operations, thus affecting the soundness of commercial banks.

\section{* Micro variables}

The micro variables that characterize the business of each commercial bank are chosen to describe the factors that affect the soundness of the banks. They also indicate the credit supply of commercial banks (Dell'Ariccia et al. 2005). De Nicolo et al. (2005) argued that the soundness of a commercial bank can be explained by its liquidity, the effectiveness of cost control, the size, and structure of its total assets.

The liquidity of commercial banks is assessed through the liquid assets-to-total assets ratio (LIQ $\mathbf{Q}_{\mathrm{it}}$ ). This ratio indicates the level of liquid assets available to meet the needs of immediate payment. The high liquidity ratio will reduce liquidity risk, improving the safety in business operations, but it will negatively affect the profitability of commercial banks.

The effectiveness of cost control is selected through the cost-to-income ratio $\left(\mathbf{C I}_{\mathbf{i t}}\right)$. In De Nicolo et al. (2007), the cost-to-income ratio will reflect the level of efficiency in banking operations in terms of cost control and is expected to have an impact on the soundness of commercial banks. 
The asset structure of commercial banks is expressed through the ratio of outstanding loans to total assets ( $\left.\mathbf{L} \mathbf{A}_{\mathrm{it}}\right)$. This high rate along with the ineffective control of credit quality will negatively affect the bank soundness. In Vietnam, where the financial market has not really developed and commercial banks are mainly seeking for profits from credit activities, the ratio of outstanding loans to total assets is expected to have a clear impact on the soundness of banking operations.

The size of assets of commercial banks will affect their competitive position as well as the development, profitability and safety. This variable is used in the form of natural logarithm of the total assets of banks (Size it $_{\text {) }}$ according to the study of Berger et al. (2005) instead of using total assets. Normally, the size of commercial banks will be positively correlated with their soundness as well as their ability to grow credit for the credit demand from their customers. This is especially suitable for commercial banks in Vietnam where there are economies of scale because state-owned commercial banks such as Agribank, Vietcombank, Vietinbank, BIDV often take advantage of their access to their customers.

Table 1. Variables

\begin{tabular}{|c|c|c|c|}
\hline \multirow{6}{*}{ 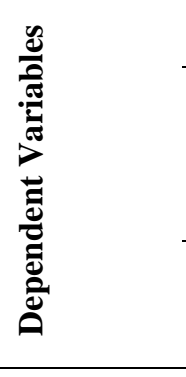 } & Variables & Description & Symbol \\
\hline & \multirow{4}{*}{$\begin{array}{l}\text { The soundness of } \\
\text { commercial banks }\end{array}$} & Profitability [Profit after Tax / Equity] & ROE $_{i t}$ \\
\hline & & Asset quality [Loan-loss Provisions/Outstanding Loans] & LLRGL $_{\text {it }}$ \\
\hline & & Capital adequacy [Equty/Total Capital] & $\mathbf{C A P}_{\text {it }}$ \\
\hline & & Distance to default $[$ zscore $=(\mathrm{ROA}+\mathrm{CAP}) / \delta \mathrm{ROA}]$ & $\mathrm{ZSCORE}_{\text {it }}$ \\
\hline & $\begin{array}{l}\text { Credit growth of } \\
\text { commercial banks }\end{array}$ & $\begin{array}{l}\text { Credit growth rate }[(\text { Outstanding Loans in the period of } t \\
\text { - Outstanding Loans in the period of } t-1) / \text { Outstanding } \\
\text { Loans in the period of } t-1)\end{array}$ & bankCrgr $_{\text {it }}$ \\
\hline \multirow{4}{*}{ 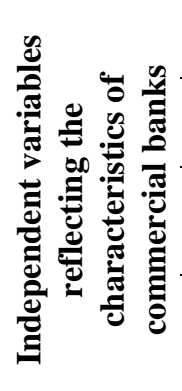 } & Size of assets & Ln (Total assets) & $\mathbf{S I Z E}_{\text {it }}$ \\
\hline & Liquidity & Liquid Assets/Total Assets & LIQ $_{\text {it }}$ \\
\hline & Structure of assets & Outstanding Loans /Total Assets & $\mathbf{L A}_{\mathbf{i t}}$ \\
\hline & $\begin{array}{l}\text { Operation } \\
\text { Effectiveness }\end{array}$ & Cost/Income & $\mathbf{C} \mathbf{I}_{\mathrm{it}}$ \\
\hline \multirow{3}{*}{ 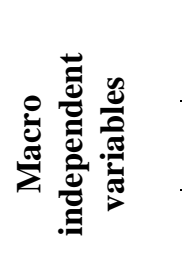 } & $\begin{array}{l}\text { The cycle of the } \\
\text { economy }\end{array}$ & Real GDP Growth Rate & RealGDP $_{\text {it }}$ \\
\hline & Interest rate & Real average Lending Interest Rates & RealIr $_{\text {it }}$ \\
\hline & Exchange rate & Annual Change of the Real Multilateral Exchange Rate & DelReeR $_{\text {it }}$ \\
\hline
\end{tabular}

\subsection{Model Specification}

The three stage least squares regression method is run simultaneously in two equations showing the relationship between credit growth and the soundness of the selected Vietnamese commercial banks.

Equation 1:

$$
\text { bankCrgr }_{\mathrm{it}}=\mathrm{f}\left(\text { bankCrgr }_{\mathrm{i}, \mathrm{t}-1} ; \text { banksoundness }_{\mathrm{i}, \mathrm{t}-1} ; \operatorname{RealGDP}_{\mathrm{t}-1} ; \operatorname{RealIr}_{\mathrm{t}-1} ; \operatorname{DelReeR}_{\mathrm{t}-1} ; \operatorname{SIZE}_{\mathrm{i}, \mathrm{t}-1} ; \mathrm{LA}_{\mathrm{i}, \mathrm{t}-1}\right)
$$

Equation 2:

Banksoundness $_{\mathrm{i}, \mathrm{t}}=\mathrm{f}\left(\right.$ bankCrgr $_{\mathrm{i}, \mathrm{t}-1} ;$ banksoundness $\left._{\mathrm{i}, \mathrm{t}-1} ; \operatorname{RealGDP}_{\mathrm{t}-1} ; \mathrm{SIZE}_{\mathrm{i},-1-1} ; \mathrm{LA}_{\mathrm{i}, \mathrm{t}-1} ; \mathrm{CI}_{\mathrm{i}, \mathrm{t}-1} ; \mathrm{LIQ}_{\mathrm{i}, \mathrm{t}-1}\right)$

Here, $i$ represents the commercial bank named $i, t$ represents year $t$. The lagged explanatory variables are also included in the equation to explain the effect-lag of credit growth and the soundness of the commercial banks. At the 
same time, the variables are given in the form of natural logarithm to assess the effect between the variables and reduce the auto-correlation between them.

Arellano (1990) found that the three-stage least squares estimation is an effective and appropriate regression model for panel data that has a short duration and uses the lagged dependent variables. Many studies have applied this regression method for models using lagged dependent variables such as Hall (1987), Igan and Pinheiro (2011) and Ghosh (2010) because of its advantages. Firstly, instead of performing regression of individual equation like the dynamic regression proposed by Arellano and Bond (1991), this method would simultaneously carry out regression of two equations to examine the reciprocal relationship between two equations. Secondly, taking account of the mutual relationship of the residuals created by the two equations after regression, this method would produce more consistent and reliable regression results than the two-stage least squares regression. Thirdly, the three stage least squares regression allows the covariance matrix of the residuals generated by the two equations to be unrestricted. Thus, the regression results are reliable, not deviated and more preferable than that of the two-stage method including lagged dependent variables in the model (Chris Brooks, 2008).

\section{Regression results}

Statistical descriptive analysis of the variables used in the regression model

Appendix 1 presents the descriptive statistics for the variables used in the regression model. It is clear that the average credit growth rate of the selected commercial banks is quite high during the research period with an average of $46.48 \%$. However, their credit growth has a great dispersion since the value of standard deviation is up to $39 \%$. Some banks even experience a negative credit growth of $15.94 \%$ whereas others have high credit growth. This reflects the reality of the structure and competition in the Vietnamese banking market. Although the number of commercial banks in Vietnam has been relatively high, most credit market shares have belonged to a small group of state-owned commercial banks. Therefore, small commercial banks have often had difficulties in terms of credit growth even in the credit boom period of the whole system due to potential limitations of resources, capital and customer base.

It is remarkable that the indicators showing the soundness of the selected commercial banks in terms of asset quality (LLRGL), profitability (ROE) and capital adequacy (CAP) seems to be improved in the period of credit boom. The rate of loan loss provision on outstanding loans is $1.28 \%$ on average while this ratio is only $1.189 \%$ in the credit boom period (2007-2010), much lowering than $1.38 \%$ of the remaining stages. Similarly, the average CAP and ROE ratios of the banks in the same period are much higher than the normal credit growth period. This may be explained by the "Financial Accelerator Mechanism" introduced by Fisher (1933) and Keyness (1932). They argued that in the credit boom, economic indicators seem to become more effective because of the impact of increased asset price and market expectations.

One of the advantages of the Zscore is that this indicator takes into account the level of risk in banking operations through the standard deviation of the return on total assets. The regression results show that Vietnamese commercial banks have operated at a high level of safety since the Zscore remains at over 30 on average throughout the period in question. However, during the credit boom, the Zscore has a lower value compared to that of the remaining period, demonstrating a decline in the bank soundness. In addition, the level of dispersion of the Zscore is very high, indicating a lack of harmonization in the operation of the Vietnamese commercial banks. This might cause the banking system to suffer systemic risk and be more vulnerable to adverse shocks in the economy.

The results also show that the proportion of outstanding loans on total assets (LA) of the banks has an average value of 55\% and the dispersion is not too high. When the economy is in a period of rapid credit growth, this rate also increases correspondingly, reflecting credit expansion at this stage. Likewise, the ratio of liquid assets to total assets (LIQ) averages $33.21 \%$ in the entire research period. The ratio declines in the credit boom because the commercial banks have given priority to the expansion of credit portfolio.

The average real credit growth is $6.22 \%$, reflecting relatively the real growth of the Vietnamese economy during the study period. However, during the period of credit boom, the real GDP growth rate is lower than that of the remaining stage. The real average lending interest rates (realIr) are lower during the credit boom. This suggests that although the credit growth in this period is high, the real lending rate is much lower than other credit growth periods because of the high inflation. With the factor of exchange rate (delReeR), it is clear that there is a depreciation of the domestic currency (VND) compared to the basket of key international currencies. This devaluation is much higher during the period of credit boom, which indicates an increase in exchange rate risk, thus negatively affecting the soundness of Vietnamese commercial banks. 
Correlation coefficients are in the range $(-1 ; 1)$, assuming a value of 1 in the case of a positive linear correlation and -1 in the case of a negative linear correlation. The correlation only shows the relationship between the variables but not the causality. Strongly correlated variables can cause multicollinearity in the regression model, affecting the accuracy of the estimation results. As shown in Kennedy (2008), the correlation between variables is strong when the absolute values of the correlation coefficients are greater than 0.80. Meanwhile, Anderson, Sweeney and Williams (1990) suggested that multicollinearity occurs when coefficients exceed 0.7. It can be seen from Appendix 2, some variables are strongly correlated including the pair of variables of (Zscore; CAP) and (realIr; delReeR). However, the correlation coefficients remain below the level that could cause auto-correlation in the regression model.

\section{Regression results}

(i) Regression results for the period 2005 - 2013

From Appendix 3, commercial banks tend to maintain high credit growth. The bankCrgr variable, which represents the credit growth rate, is always positive in all four regression equations and is statistically significant. The results indicate that commercial banks with a higher level of soundness would likely continue to grow credit. When commercial banks have a higher Zscore coefficient in the previous year, they focus more on credit expansion in the following year. Likewise, improved CAP and ROE ratios allow commercial banks to be more willing to increase credit to seek profits. The negative sign of the coefficient of LLRGL also shows that the higher risk provisioning ratio along with the deteriorated loan portfolio quality makes commercial banks more cautious in the expansion of credit. This is reasonable because if the profitability, as well as the bank soundness, are improved, they may be willing to take higher risks in increasing credit growth for seeking profit.

It is worth noting that credit growth in Vietnamese commercial banks seems to be higher and mainly belongs to small scale commercial banks because the variable Size takes negative values in all equations and is statistically significant at $10 \%$. Thus, although large commercial banks have advantages in terms of extending credit as they are more competitive in cost and capital than small commercial banks, these banks are more cautious in credit growth. In contrast, small commercial banks are willing to increase rapidly credit to seek market share and profit. This will negatively affect the quality of credit growth since smaller banks are more willing to lend to high-risk customers and lower their lending standards for credit growth. Therefore, the commercial banks system will be more vulnerable when adverse events occur to the economy.

The realGDP variable shows the impact of the business cycle on the credit growth of commercial banks. The regression results indicate the existence of procyclicality for the credit capital of Vietnamese commercial banks as the coefficient of the realGDP variable is positive and statistically significant in all the equations. Bank credit usually grows sharply during a period of economic growth due to the expansion of investment and the aggregate demand in the economy. This helps to keep real credit growth in Vietnam at a relatively high level, averaging over $6 \%$. However, when the economy is growing fast, credit decisions are often "over-optimistic" with a continuous increase in the value of assets and corporate value, making lending decisions easier and riskier.

The coefficients of RealIr and delReeR variables have the same sign in line with expectations, however, are not statistically significant enough in the research equations for the entire 2005-2013 period. This suggests that the volatility of real interest rates and changes in foreign exchange rates seem to have little impact on lending decisions of Vietnamese commercial banks.

\section{The assessment of the soundness of commercial banks}

In terms of profitability (ROE), high credit growth makes commercial banks more lucrative. This is perfectly applicable to Vietnamese commercial banks which credit activities are still the primary one and generate most their income. The ratio of outstanding loans on total assets (LA) has a positive impact on the profitability of commercial banks. Hence, high credit growth demonstrates the expansion of lending activities and enables commercial banks to generate higher incomes and improve profitability. The results also show that the larger the size of commercial banks is, the higher the profitability is because of their competitive advantage. The profitability of commercial banks is also improved while the economy is in a high growth period with the expansion of the credit portfolio. The relationship between ROE and credit growth (realGDP) reflects the dependence of the economy on bank credit when the financial market is still incomplete.

Regarding capital structure (CAP), credit growth has a negative impact the ratio of equity on total capital. This proves that in order to finance their loan portfolio, commercial banks use mainly deposits and mobilized funds instead of using equity. However, this relationship is not statistically significant enough, indicating the dispersion in the use of funds to finance lending among commercial banks. 
Relating to asset quality, credit growth and credit risk provision ratios are negatively correlated but not statistically significant. This can be explained by the lack of consistency in regulations on classification and provisioning of credit risk in Vietnamese commercial banks. The positive sign of LLRGL's lagged coefficient with a high confidence indicates that ineffective commercial banks with a higher level of credit risk also have a significant impact on asset quality in the following period. The regression findings also show that large commercial banks appear to have a higher level of credit risk and risk provisioning. This may be because large commercial banks have made credit risk provision more in line with the quality of their loans and in accordance with international practice.

In regard to the distance to default (Zscore), the statistical results clearly show the negative impact of credit growth on the soundness of commercial banks through the negative sign and the high statistical significance of the coefficient of the bankCrgr variable. Larger scale commercial banks have higher zscore coefficients, thus operating at a higher level of safety than small-scale commercial banks. It is remarkable that commercial banks that focus more on lending have a safer level of business activities. In Vietnam, this is relatively reasonable because developing diversified business in the undeveloped financial market brings higher levels of risk. In other words, commercial banks, which operate mainly in the traditional lending sector in Vietnam, have a lower level of risk.

\section{(ii) Regression results for the period of credit boom (2007-2010)}

For credit growth, the statistic results indicate that the credit growth in the previous year has an impact on credit growth in the latter year. However, during the credit boom, high credit growth is not determined by the banks' desire because the coefficient of BankCrgr variable is lower relative to that in whole sample analysis.

Regarding profitability, in this stage the commercial banks pay more attention to profitability since the coefficient of ROE is positive and statistically significantly higher than that in the overall equation. The coefficient of CAP is the same sign but with a smaller value than that in the overall equation, indicating that the commercial banks accept higher leverage and increase deposits for credit expansion compared to normal credit growth periods. During the credit boom, weak commercial banks tried to speed up credit growth whereas sound banks were able to increase credit at moderate rates.

In terms of size, the results show that the size of commercial banks is not the decisive factor for their high credit growth. In other words, there is a dispersion in the decision to grow credit at commercial banks of different scales. At this stage, some small commercial banks started to be established and try to expand their operation in the context of rapid economic development. The impact of scale on credit growth is very blurred, which can be attributed to the change and turmoil in lending market share during this period. The negative coefficient of LA indicates that small commercial banks appear to be more proactive in boosting credit growth.

In this period the commercial banks did not seem to pay much attention to the economic growth rate since the coefficient of realGDP is not statistically significant in the most equations. In contrast, real lending rates and changes in the real exchange rate are significant for credit growth. When real average lending rates increase, commercial banks are more willing to extend credit because of their increased benefits. Meanwhile, VND continued to depreciate during this period as the State Bank of Vietnam devalued VND in order to protect the competitiveness of domestic goods. This is considered to be a factor that constrains the credit growth of commercial banks.

\section{The assessment of the soundness of commercial banks}

Relating to ROE, accelerating credit growth helps to improve the ROE of commercial banks. In fact, the improvement of ROE at this stage is much lower than normal credit growth periods, which shows that the effectiveness of credit is reduced considerably. ROE of large commercial banks is higher than that of small-scale commercial banks as a result of economies of scale.

In terms of capital structure (CAP), similar to the results from the research equation for the whole study period, there is no statistical significance in the impact of capital structure on the credit boom, though it appears that commercial banks with a higher risk will be more willing to grow credit.

Regarding asset quality (LLRGL), the positive and significant correlation of bankCrgr variable indicates that credit growth has a negative impact on the quality of assets of commercial banks. This is consistent with previous studies on the relationship of credit growth and portfolio quality such as Dell'Aricca and Marquez (2006), Borio and Lowe (2002), Mendoza and Terrones (2008). Speeding up credit growth along with lowering commercial banks' lending standards leads to a corresponding increase in non-performing loans and provisioning for credit losses, causing the risk of the banks to increase. 
In regard to the distance to default (Zscore), the credit boom has had a strong negative impact on the soundness of commercial banks. $1 \%$ of credit growth causes the commercial bank's Zscore coefficient to decrease by $0.09 \%$ in this period compared to $0.02 \%$ for the whole study period. This continues to illustrate that when commercial banks pay too much attention to high-speed credit growth, they negatively affect their performance.

\section{Conclusions and Recommendations}

This study provides an extensive research on the impacts of rapid credit expansion periods recently to the soundness of Vietnamese commercial banks. Since the banking system plays a vital role in the country's economic growth, mainly through the credit channels, it is important to ensure the safety and soundness in the operations of commercial banks. This study, therefore, shed the lights on the effects of Vietnamese commercial banks recent lending activities to their efficiency, profitability, asset quality and capital structure. Both qualitative analysis and quantitative investigations using the large data sample from 2005-2013 confirm negative effects of credits booms periods to the soundness and efficiency of Vietnamese commercial banks. The rapid credit growth, on the one hand, helps increasing bank profit as bank lending is still the main source of incomes in all Vietnamese banking system. On the other hand, however, higher credit growth on average worsen the asset quality, decrease the bank distance to default and leads to smaller capital shield. A remarkable reason is the over-activity of smaller and less efficient banks in bank lending to seek profits and market share throughout the sample periods. During the credit boom period with peaking credit demands in the economy, these risky lending behaviours lead to more negative effects to the bank soundness, provoking NPLs, rising liquidity problem, and systemic risks. The authors, therefore, would propose several policy recommendations to limit the possibility of unexpected credit booms in the future and its negative impacts on the soundness of the banking system in Vietnam.

\section{Recommendations on indicators for early warning of credit booms}

In order to avoid the consequences of credit booms, early warning indicators for potential credit booms need to be introduced before providing solutions to ensure credit growth in line with the capital absorption capacity of the economy.

The Credit-to-GDP gap ("credit gap") is defined as the difference between the credit-to-GDP ratio and its long-term trend. It is one of the basic indicators used to early warn credit booms (Borio and Lowe, 2002). This is because it is necessary to consider credit growth in relation to the capacity of capital absorption of the economy which is reflected by the economic growth rate. As shown in BIS (2010), the $2 \%$ threshold is appropriate for early warning of credit booms in some countries with $87 \%$ confidence based on past banking crises. Given the specific financial depth and the development of the financial market in Vietnam, the $2 \%$ threshold for the Credit-to-GDP gap might be considered for Vietnam in early warning of credit booms.

The real economic growth can be used as a second reliable indicator since, during periods of high real GDP growth, the credit demand of the economy has increased sharply for consumption and investment. Furthermore, substantial changes in asset prices, especially the two major assets, real estate and stocks, might be other indicators for early warning of credit booms and the risks to the banking system. They represent potential risks when bank lending grows too fast but is primarily directed toward high-risk economic sectors such as real estate and stock trading. Similar to the Credit-to-GDP gap, the gap between the house price-to-per capita income ratio and its long-term trend at more than $2 \%$ indicates a sign of a credit boom period.

\section{Recommendations aiming to improve the supervisory role of regulatory authorities}

Firstly, the SBV needs to raise transparency of commercial banks in terms of risk management methods and policies.

Secondly, the SBV should require commercial banks to carry out stress test regularly, offering specific solutions in bad cases for the reversal of the credit cycle and that of the economy.

Thirdly, the SBV should change its supervisory model based mainly on compliance into the risk-based supervision model.

Lastly, in addition to the application of macroprudential surveillance for commercial banks, the SBV needs to improve supervisor of non-bank credit institutions.

Recommendations for commercial banks

Firstly, commercial banks need to raise awareness about the risks associated with rapid credit growth.

Secondly, credit risk management needs to be improved, focusing on some aspects such as identifying risk appetite, improving the model of credit risk management, promoting awareness of credit risk and measure it. 
Lastly, commercial banks should implement a planned loan portfolio management to avoid credit growth focusing on high-risk sectors such as real estate and stock trading.

\section{References}

Anderson, D.R., Seeney, D.J., \& Williams, T.A. (1990). An Introduction to Management Science: A Quantitative Approach to Decision Making. Lincoln, LIN, United Kingdom

Arellano, M. (199). Testing for Autocorrelation in Dynamic Random Effects Models. Review of Economic Studies, 57(1), 127-34.

Arellano, M., \& Stephen Roy Bond. (1991). Some Tests of Specification for Panel Data: Monte Carlo Evidence and an Application to Employment Equations. Review of Economic Studies, 58(2), 277-97.

Banking Academy. (2013). Bank lending for economic growth - Issues in the first quarter of 2013 and some policy recommendations (Tín dụng ngân hàng phục vụ tăng trưởng kinh tế - Những vấn đề đặt ra trong quí 1 năm 2013 và một số khuyến nghị chính sách), in the workshop at Banking Academy in Vietnam in 2013/

Barajas, A., Dell'Ariccia, G., \& Levchenko, A. (2007). Credit Booms: The Good, the Bad, and the Ugly. IMF Working Paper (Washington: International Monetary Fund).

Berger, A.N., Clarke, G.R., Cull, R., Klapper, L., \& Udell, G. (2005). Corporate governance and bank performance: a joint analysis of the static, selection, and dynamic effects of domestic, foreign, and state ownership. Journal of Banking and Finance, 29, 2179-2221.

Berger, Allen N., \& Gregory F. Udell. (2004). The Institutional Memory Hypothesis and the Procyclicality of Bank Lending Behavior. Journal of Financial Intermediation, 13(4), 458-95.

Black, F., \& Sholes, M. (1973). The Pricing of Options and Corporate Liabilities. Journal of Political Economy, 81(3), 637-54.

Borio, C. F. C., \& Lowe, P. (2002). Asset prices, financial and monetary stability: exploring the nexus, BIS WP 114.

De Nicolo, G., \& Loukoianova, E. (2007). Bank Ownership, Market Structure and Risk. IMF Working Paper No. $\mathrm{WP} / 07 / 215$.

De Nicoló, G., et al.. (2005). European Financial Integration, Stability and Supervision. In Euro Area Policies; Selected Issues, by Anthony Annett and others, IMF Country Report No. 05/266 (Washington: International Monetary Fund).

Dell'Ariccia, G., \& Marquez, R. (2006). Lending Booms and Lending Standards. Journal of Finance, 61(5), 2511-46.

Dell'Ariccia, G., Detragiache, E., \& Rajan, R. (2005). The Real Effect of Banking Crises. IMF Working Paper No. 05/63 (Washington: International Monetary Fund).

Fisher. (1933). The Debt-Deflation Theory of Great Depressions. Economica, 1, 337-57.

Ghosh, S. (2010, March). Credit Growth, Bank Soundness and Financial Fragility: Evidence from Indian Banking Sector. South Asia Economic Journal, 11, 69-98.

Goddard, J., Molyneux, P., \& Wilson, J. (2004). The profitability of European banks: A cross-sectional and dynamic panel analysis. The Manchester School, 72, 363-81.

Gourinchas, P.O., Valdes, R., \& Landerretche, O. (2001). Lending Booms: Latin America and the World. Economia, Spring Issue, 47-99.

Hall, S.G. (1987). A Forward "Looking Model of the Exchange Rate". Journal of Applied Econometrics, 2(1), 47-60.

Hoffmann, P. S. (2011). Determinants of the Profitability of the US Banking Industry. International Journal of Business and Social Science, 2(22).

Igan, A., \& Pinheiro, M. (2011). Credit Growth and Bank Soundness: Fast and Furious?. IMF Working Paper.

Kennedy, P. (2008). A Guide to Econometric (6th ed.). Blackwell Publishing, Malden.

Keynes, J. (1932). The Concequences to the Banks of the Collapse of Money Value. In Essays in Persuasion (Chapter 7). New York: Harcourt, Brace and Company.

Kindleberger, C. P. (1977). Economic Development. New York: McGraw-Hill, 1958, 1965, (and with Bruce Herrick) 1977, 1983. 
KPMG. (2013). Survey on Vietnam's banking industry in 2013 (Khảo sát về ngành ngân hàng Việt Nam năm 2013). Retrieved from kpmg.com.vn

Mendoza, Enrique G., \& Marco Terrones. (2008). An Anatomy of Credit Booms: Evidence from Macro Aggregates and Micro Data. IMF Working Paper No. 08/226 (Washington: International Monetary Fund).

Merton, R. C. (1974). On the Pricing of Corporate Debt: The Risk Structure of Interest Rates. Journal of Finance, 29(2), 449-70.

Quach Manh Hao. (2012). The weaknesses of the banking system in Vietnam (Những điểm yếu của hệ thống ngân hàng Việt Nam hiện nay). Journal of Science, Vietnam National University Hanoi, Vietnam, (28), 23-28

Sirtaine, S., \&Skamnelos, I. (2007). Credit Growth in Emerging Europe: ACause for Stability Concerns?. World Bank Policy Research working Paper No. 4281

To Ngoc Hung. (2013). Measures to deal with non-performing loans in the process of restructuring commercial banks in Vietnam (Xử lý nợ xấu trong quá trình tái cấu trúc ngân hàng thương mại Việt Nam), Project of State Bank of Vietnam.

Websites of the Vietstock, Stoxplus, State Bank of Vietnam, National Financial Supervisory Commission of Vietnam, General Statistics Office of Vietnam, IMF, WB...

Appendix 1. Descriptive statistics of variables

\begin{tabular}{|c|c|c|c|c|c|c|c|c|c|c|c|c|c|c|c|}
\hline & Obs & Mean & Std & Min & Max & Obs & Mean & Std & Min & Max & Obs & Min & Std & Min & Max \\
\hline \multicolumn{16}{|c|}{ Dependent Variables } \\
\hline bankCrgr & 126 & 46.581 & 39.001 & -15.938 & 180.044 & 66 & 68.045 & 37.888 & 13.385 & 180.043 & 60 & 22.971 & 23.641 & -15.938 & 99.140 \\
\hline LLRGL & 135 & 1.286 & 0.816 & 0.013 & 4.341 & 67 & 1.1898 & 0.871 & 0.151 & 4.341 & 68 & 1.3811 & 0.753 & 0.013 & 3.181 \\
\hline CAP & 136 & 10.701 & 5.718 & 3.799 & 40.814 & 67 & 10.8045 & 4.581 & 5.004 & 26.621 & 69 & 10.601 & 6.672 & 3.799 & 40.814 \\
\hline ROE & 136 & 14.266 & 6.992 & 1.197 & 44.253 & 67 & 15.610 & 6.791 & 4.005 & 44.253 & 69 & 12.961 & 6.985 & 1.197 & 33.937 \\
\hline Zscore & 136 & 30.516 & 16.743 & 7.3793 & 114.097 & 67 & 30.098 & 12.995 & 9.528 & 71.370 & 69 & 30.921 & 19.806 & 7.379 & 114.097 \\
\hline \multicolumn{16}{|c|}{ Independent Variables } \\
\hline SIZE & 136 & 24.017 & 3.145 & 12.395 & 27.080 & 67 & 23.963 & 2.899 & 13.199 & 26.631 & 69 & 24.069 & 3.389 & 12.396 & 27.080 \\
\hline LA & 136 & 55.005 & 13.655 & 30.009 & 84.477 & 67 & 55.511 & 14.182 & 30.009 & 84.477 & 69 & 54.678 & 13.192 & 30.262 & 81.012 \\
\hline CI & 135 & 42.833 & 11.552 & 24.412 & 80.119 & 67 & 40.089 & 10.224 & 25.145 & 80.119 & 68 & 45.537 & 12.205 & 24.412 & 77.963 \\
\hline LIQ & 134 & 33.212 & 14.699 & 3.535 & 91.60 & 67 & 33.164 & 12.337 & 8.107 & 72.327 & 67 & 33.260 & 16.829 & 3.535 & 91.609 \\
\hline RealGDP & 153 & 6.227 & 0.804 & 5.247 & 7.547 & 85 & 6.153 & 0.683 & 5.398 & 7.130 & 85 & 6.287 & 0.888 & 5.247 & 7.547 \\
\hline RealIr & 153 & 0.9493 & 3.253 & -5.616 & 5.357 & 85 & 0.093 & 3.474 & -5.6163 & 3.628 & 85 & 1.634 & 2.908 & -3.552 & 5.357 \\
\hline DelReeR & 153 & -7.819 & 10.417 & -18.189 & 17.961 & 85 & -13.520 & 3.488 & -18.189 & -8.731 & 85 & -3.257 & 11.802 & -17.151 & 17.961 \\
\hline
\end{tabular}

Source: Authors' calculation

Obs: Number of Observations, Mean: Mean, Std: Standard Deviation, Max: Maximum value, Min: Minimum value

BankCrgr: Annual Credit Growth Rate, LLRGL: Loan-Loss Provisions/Outstading Loans, CAP: Equity/Total

Capital, ROE: Profit after Tax / Equity, Zscore: (ROA + CAP)/SROA, SIZE: $\ln$ (Total Assets), LIQ: Liqui Assets/Total Assets, CI: Cost/Income, LA: Outstanding Loans /Total Assets, RealGDP: Real GDP Growth Rate,

RealIr: Real Average Lending Interest Rates, DelReer: Annual Change of the Real Multilateral Exchange Rate 
Appendix 2. The matrix of the correlations between the variables

\begin{tabular}{|c|c|c|c|c|c|c|c|c|c|c|c|c|}
\hline Variables & LLRGL & CAP & ROE & CI & LA & SIZE & LIQ & Zscore & bankCrgr & RealGDP & RealIr & DelReeR \\
\hline LLRGL & 1.000 & & & & & & & & & & & \\
\hline CAP & -0.2189 & 1.000 & & & & & & & & & & \\
\hline ROE & 0.0287 & -0.386 & 1.000 & & & & & & & & & \\
\hline CI & -0.0596 & -0.149 & -0.484 & 1.000 & & & & & & & & \\
\hline LA & 0.033 & 0.305 & -0.276 & 0.142 & 1.000 & & & & & & & \\
\hline SIZE & 0.286 & -0.576 & 0.200 & 0.189 & -0.252 & 1.000 & & & & & & \\
\hline LIQ & -0.132 & -0.018 & 0.277 & -0.4001 & -0.619 & -0.209 & 1.000 & & & & & \\
\hline ZSCORE & 0.060 & 0.601 & -0.284 & -0.216 & 0.395 & -0.278 & -0.135 & 1.000 & & & & \\
\hline bankCrgr & -0.356 & 0.203 & 0.154 & -0.211 & -0.002 & 0.016 & -0.016 & 0.171 & 1.000 & & & \\
\hline RealGDP & -0.264 & -0.095 & 0.309 & -0.417 & 0.005 & -0.128 & 0.343 & -0.002 & 0.047 & 1.000 & & \\
\hline RealIr & -0.006 & -0.090 & -0.048 & 0.044 & 0.135 & 0.020 & -0.086 & -0.048 & -0.129 & -0.077 & 1.000 & \\
\hline DelReeR & 0.09 & -0.090 & -0.236 & 0.294 & 0.102 & 0.044 & -0.157 & -0.062 & -0.291 & -0.270 & 0.636 & 1.000 \\
\hline
\end{tabular}

Sources: The Authours' calculations

Appendix 3. Regression results

\begin{tabular}{|c|c|c|c|c|c|c|c|c|}
\hline \multirow[t]{3}{*}{ Variables } & \multicolumn{8}{|c|}{ Panel A: 2005-2013 } \\
\hline & \multicolumn{2}{|c|}{ Equation 1} & \multicolumn{2}{|c|}{ Equation 2} & \multicolumn{2}{|c|}{ Equation 3} & \multicolumn{2}{|c|}{ Equation 4} \\
\hline & bankCr & ROE & bankCr & CAP & bankCrgr & LLRGL & bankCrgr & Zscore \\
\hline \multirow[t]{2}{*}{ bankCrgr } & $0.422^{\mathrm{a}}$ & $0.102^{\mathrm{a}}$ & $0.376^{\mathrm{a}}$ & -0.016 & $0.413^{\mathrm{a}}$ & -0.034 & $0.385^{\mathrm{a}}$ & $-0.021^{\mathrm{b}}$ \\
\hline & $(0.098)$ & $(0.037)$ & $(0.098)$ & $(0.015)$ & $(0.099)$ & $(0.046)$ & $(0.097)$ & $(0.013)$ \\
\hline \multirow[t]{2}{*}{ ROE } & $-0.026^{c}$ & $0.037^{a}$ & & & & & & \\
\hline & $(0.019)$ & $(0.008)$ & & & & & & \\
\hline \multirow[t]{2}{*}{ CAP } & & & $0.763^{b}$ & $0.798^{\mathrm{a}}$ & & & & \\
\hline & & & $(0.355)$ & $(0.052)$ & & & & \\
\hline \multirow[t]{2}{*}{ LLRGL } & & & & & -0.208 & $0.462^{\mathrm{a}}$ & & \\
\hline & & & & & $(0.164)$ & $(0.082)$ & & \\
\hline \multirow[t]{2}{*}{ Zscore } & & & & & & & $0.700^{\mathrm{a}}$ & $0.853^{\mathrm{a}}$ \\
\hline & & & & & & & $(0.275)$ & $(0.038)$ \\
\hline \multirow[t]{2}{*}{ SIZE } & $-0.061^{\mathrm{c}}$ & $0.014^{\mathrm{b}}$ & $-0.012^{c}$ & $0.009^{c}$ & $-0.049^{c}$ & $0.038^{\mathrm{b}}$ & $-0.053^{c}$ & $0.006^{\mathrm{c}}$ \\
\hline & $(0.045)$ & $(0.017)$ & $(0.051)$ & $(0.007)$ & $(0.047)$ & $(0.022)$ & $(0.044)$ & $(0.040)$ \\
\hline \multirow[t]{2}{*}{$\mathbf{L A}$} & -0.207 & $0.204^{b}$ & -0.234 & 0.14988 & 0.071 & -0.099 & -0.522 & $0.208^{b}$ \\
\hline & $(0.486)$ & $(0.177)$ & $(0.470)$ & $(0.079)$ & $(0.477)$ & $(0.321)$ & $(0.496)$ & $(0.074)$ \\
\hline \multirow[t]{2}{*}{ CI } & & 0.033 & & -0.043 & & -0.226 & & $-0.101^{b}$ \\
\hline & & $(0.201)$ & & $(0.078)$ & & $(0.303)$ & & $(0.071)$ \\
\hline \multirow[t]{2}{*}{ LIQ } & & 0.072 & & 0.008 & & -0.083 & & 0.013 \\
\hline & & $(0.126)$ & & $(0.051)$ & & $(0.232)$ & & $(0.044)$ \\
\hline \multirow[t]{2}{*}{ RealGDP } & $0.161^{\mathrm{b}}$ & $0.021^{\mathrm{c}}$ & $0.195^{b}$ & $0.037^{c}$ & $0.155^{\mathrm{c}}$ & $-0.062^{c}$ & $0.161^{b}$ & $0.004^{c}$ \\
\hline & $(0.168)$ & $(0.007)$ & $(0.167)$ & $(0.029)$ & $(0.173)$ & $(0.093)$ & $(0.169)$ & $(0.026)$ \\
\hline \multirow[t]{2}{*}{ RealIr } & -0.010 & & -0.014 & & -0.034 & & -0.018 & $0.658^{a}$ \\
\hline & $(0.060)$ & & $(0.061)$ & & $(0.063)$ & & $(0.062)$ & $(0.176)$ \\
\hline \multirow[t]{2}{*}{ DelReer } & 0.001 & & 0.027 & & 0.034 & & 0.034 & $-0.678^{a}$ \\
\hline & $(0.041)$ & & $(0.043)$ & & $(0.044)$ & & $(0.043)$ & $(0.172)$ \\
\hline Nobs & 101 & 101 & 101 & 101 & 101 & 101 & 101 & 101 \\
\hline $\bar{R}^{2}$ & 0.307 & 0.769 & 0.330 & 0.793 & 0.304 & 0.510 & 0.344 & 0.798 \\
\hline
\end{tabular}




\begin{tabular}{|c|c|c|c|c|c|c|c|c|}
\hline \multirow[t]{3}{*}{ Variables } & \multicolumn{8}{|c|}{ Panel B: 2007-2010 } \\
\hline & \multicolumn{2}{|c|}{ Equation 1} & \multicolumn{2}{|c|}{ Equation 2} & \multicolumn{2}{|c|}{ Equation 3} & \multicolumn{2}{|c|}{ Equation 4} \\
\hline & bankCrgr & ROE & bankCrgr & CAP & bankCrgr & LLRGL & bankCrgr & Zscore \\
\hline bankCrgr & $0.240^{\mathrm{a}}$ & 0.024 & $0.193^{\mathrm{a}}$ & -0.040 & $0.189^{\mathrm{a}}$ & $0.018^{\mathrm{c}}$ & $0.216^{\mathrm{a}}$ & $-0.094^{b}$ \\
\hline & $(0.066)$ & $(0.072)$ & $(0.065)$ & $(0.057)$ & $(0.065)$ & $(0.047)$ & $(0.065)$ & $(0.075)$ \\
\hline ROE & $\begin{array}{l}-0.2352^{b} \\
(0.138)\end{array}$ & $\begin{array}{l}0.566^{\mathrm{a}} \\
(0.180)\end{array}$ & & & & & & \\
\hline CAP & & & $\begin{array}{l}0.470^{\mathrm{a}} \\
(0.177)\end{array}$ & $\begin{array}{l}0.597^{\mathrm{a}} \\
(0.152)\end{array}$ & & & & \\
\hline LLRGL & & & & & $\begin{array}{l}-0.260^{\mathrm{a}} \\
(0.094)\end{array}$ & $\begin{array}{c}0.657^{\mathrm{a}} \\
(0.073)\end{array}$ & & \\
\hline Zscore & & & & & & & $\begin{array}{l}0.313^{\mathrm{b}} \\
(0.151)\end{array}$ & $\begin{array}{l}0.563^{\mathrm{a}} \\
(0.170)\end{array}$ \\
\hline SIZE & $\begin{array}{l}-0.011 \\
(0.023)\end{array}$ & $\begin{array}{l}0.041^{\mathrm{b}} \\
(0.028)\end{array}$ & $\begin{array}{c}0.016 \\
(0.025)\end{array}$ & $\begin{array}{l}-0.020 \\
(0.023)\end{array}$ & $\begin{array}{c}0.011 \\
(0.024)\end{array}$ & $\begin{array}{l}-0.018^{\mathrm{c}} \\
(0.019)\end{array}$ & $\begin{array}{l}-0.009 \\
(0.023)\end{array}$ & $\begin{array}{l}0.010^{\mathrm{c}} \\
(0.027)\end{array}$ \\
\hline LA & $\begin{array}{l}-0.871^{\mathrm{a}} \\
(0.234)\end{array}$ & $\begin{array}{l}0.199 \\
(0.431)\end{array}$ & $\begin{array}{l}-0.852^{a} \\
(0.224)\end{array}$ & $\begin{array}{l}0.688^{\mathrm{b}} \\
(0.327)\end{array}$ & $\begin{array}{l}-0.594^{\mathrm{b}} \\
(0.236)\end{array}$ & $\begin{array}{c}-0.00 \\
(0.295)\end{array}$ & $\begin{array}{l}-0.982^{\mathrm{a}} \\
(0.243)\end{array}$ & $\begin{array}{l}0.499^{\mathrm{a}} \\
(0.247)\end{array}$ \\
\hline CI & & $\begin{array}{l}0.706^{\mathrm{b}} \\
(0.378)\end{array}$ & & $\begin{array}{c}0.237 \\
(0.245)\end{array}$ & & $\begin{array}{c}0.075 \\
(0.208)\end{array}$ & & $\begin{array}{l}0.513^{c} \\
(0.329)\end{array}$ \\
\hline LIQ & & $\begin{array}{l}0.604^{\mathrm{b}} \\
(0.268)\end{array}$ & & $\begin{array}{l}0.664^{\mathrm{a}} \\
(0.208)\end{array}$ & & $\begin{array}{c}-0.062 \\
(0.169)\end{array}$ & & $\begin{array}{l}0.409^{\mathrm{a}} \\
(0.217)\end{array}$ \\
\hline RealGDP & $\begin{array}{l}-0.222^{c} \\
(0.191)\end{array}$ & $\begin{array}{l}-0.181^{\mathrm{b}} \\
(0.099)\end{array}$ & $\begin{array}{l}-0.065 \\
(0.189)\end{array}$ & $\begin{array}{c}0.081 \\
(0.0787\end{array}$ & $\begin{array}{l}-0.192^{c} \\
(0.192)\end{array}$ & $\begin{array}{l}0.169^{\mathrm{b}} \\
(0.073)\end{array}$ & $\begin{array}{l}-0.196^{c} \\
(0.187)\end{array}$ & $\begin{array}{c}0.000 \\
(0.105)\end{array}$ \\
\hline RealIr & & $\begin{array}{l}0.410^{\mathrm{b}} \\
(0.178)\end{array}$ & & $\begin{array}{l}0.477^{\mathrm{a}} \\
(0.168)\end{array}$ & & $\begin{array}{l}0.552^{\mathrm{a}} \\
(0.169)\end{array}$ & & \\
\hline DelReer & & $\begin{array}{l}-0.430^{b} \\
(0.175)\end{array}$ & & $\begin{array}{l}-0.510^{a} \\
(0.165)\end{array}$ & & $\begin{array}{l}-0.575^{\mathrm{a}} \\
(0.166)\end{array}$ & & \\
\hline Nobs & 51 & 51 & 51 & 51 & 51 & 51 & 51 & 51 \\
\hline $\bar{R}^{2}$ & 0.442 & 0.388 & 0.479 & 0.517 & 0.486 & 0.746 & 0.534 & 0.519 \\
\hline
\end{tabular}

Sources: The Authours' own estimations

The above table shows the regression results of the model about relationship between credit growth and the soundness of commercial banks with three stage least squares estimation. Panel A shows analysis for the whole data sample from 2005 - 2013. Panel B shows estimation results for the credit boom period in Vietnamese banking system (2007-2010). The symbols $a, b$ and $c$ represents significant levels at $1 \%, 5 \%$ and $10 \%$ respectively. 